Arab World English Journal (AWEJ) Volume 12. Number4 September 2021

DOI: https://dx.doi.org/10.24093/awej/vol12no4.17

Pp. 243-258

\title{
Exploring Students' Perceptions and Attitudes towards Genre-based Pedagogy Developed in Persuasive Writing Teaching: The Systemic Functional Linguistics Perspective
}

\author{
FENG CHEN \\ Department of English, School of Human Science \\ Assumption University, Bangkok, Thailand \\ Email: 406956449@qq.com
}

Received: 9/15/2021 Accepted: 10/4/2021 Published: 12/15/2021

\begin{abstract}
Previous studies in genre-based pedagogy mainly concerned with its teaching effects, few studies involved with students' perceptions and attitudes which is actually playing a role in teaching and learning activities. The present study intends to make some explorations in this aspect. A quasiexperimental study to designed to answer the research question "What are students' perceptions and attitudes towards the genre-based pedagogy developed in Chinese university students' persuasive writings?" Thirty-four students participated in the study and a four-point Likert scale questionnaire and an interview were applied to collect the data. After the quantitative and qualitative analysis, the study find that most participants hold positive attitudes towards every item of the questionnaire and think highly of the genre-based teaching pedagogy from the following six aspects: the mastery of textual features, the genre-awareness of persuasion, confidence in writing an effective persuasion, attitudes towards group writing in the teaching instruction, interests in the application of the curriculum cycle to other genres and other program instruction related comments such as being difficult to master certain required language features and following the teaching patterns involved in the textual construction of persuasion. However, the general indication is that the curriculum cycle can help and enhance students' understandings of each of the textual features of persuasion. Finally, the study provides implications for future teaching: the genre-based approach could be effectively and widely applied in Chinese university students' genre writing as the apprenticeship involved allows the students to be more creative as their writing skills develop.

Keywords: attitudes, genre-based pedagogy, perceptions, persuasive writing, systemic functional linguistics
\end{abstract}

Cited as Feng, C. (2021). Exploring Students' Perceptions and Attitudes towards Genre-based Pedagogy Developed in Persuasive Writing Teaching: The Systemic Functional Linguistics Perspective. Arab World English Journal, 12 (4). 243-258.

DOI: https://dx.doi.org/10.24093/awej/vol12no4.17 


\section{Introduction}

In the EFL teaching and learning context, writing has always been a difficult area although both teachers and students devote extensive energy and time to it. It may very well be because writing involves many factors such as generation, analysis, ideas, organization, sentence structure, vocabulary, spelling and mechanics etc., which makes writing a multidimensional complex process William (2007, p. 12). While it is essential for foreign language learners to develop their abilities to write as Raimes (1983) pointed out writing helped students learn. (p. 19). Researchers and teachers are always finding different approaches to writing and theories experience several stages of development. Generally speaking, there are three typical approaches: the product approach, the process approach and the genre-based approach. The product approach originated in the 1960s, emphasizing accuracy of form based on the idea that learning is the product of forming habits (Silva, 1990). Later in the 1970s, ESL writing moved from the traditional language-based approach to the process approach. The process approach focuses on the writer's thoughts and the importance of repeated thinking, and pays less attention to readers (Silva, 1990). Then in the early 1980s, in order to bridge the gap between product and process writing approaches, the genre-based approach evolved as a development to these two approaches.The teaching principle of genre-based approach is to help students learn to understand generic texts, to recognize the generic patterns and related language features they encounter within texts (Price \& Price, 2002). There are three broad and overlapping schools of genre theory: the New Rhetoric approach, the ESP approach and the Sydney School, the latter was based on the socially-based language studies of Systemic Functional Linguistics (SFL). The main target is to analyze the relationship between social contexts and linguistic aspects (Halliday \& Matthiessen, 2014). This school of genre theory was first proposed by Halliday (1978), later developed by Derewianka (1990), Foley (2011), Rothery (1989, 1996), Rose and Acevedo (2006), Rose and Martin (2012), etc. It is found the most appropriate and persuasive theory in analyzing lexico-grammatical features of genre writing. In particular classroom teaching, the genre-based approach is widely applied through "curriculum cycle". It emphasizes the explicit instruction on controlling generic structural patterns and lexico-grammatical features of a particular genre, and collaborative writing. Based on these, the present study put forward the research question "What are students' perceptions and attitudes towards the genre-based pedagogy developed in Chinese university students' persuasive writing?" to explore students' perceptions and attitudes towards this widely applied writing pedagogy in the EFL contexts and to provide implications for Chinese English writing teaching and assessing in China.

\section{Literature Review}

SFL is a theory of language centered around the notion of language functions. The SFL is the most fully elaborated and useful system for discourse analysis and various areas of applied linguistics. The genre-based approach informed by SFL was first developed in Australia and associated with the Sydney School Project. The project was conducted within Bernstein's (1975) framework of deconstructions of traditional progressive pedagogy and detailing the pedagogy. Later, the project influenced other educational systems in Australia, and had been adopted in primary, secondary, tertiary, professional and community teaching contexts in programs for native speakers of English as well as ESL and EFL learners. Educators in countries as diverse as Singapore, South Africa, USA, Italy, Hong Kong, Australia, UK, China, Canada, Sweden, 
Indonesia and Thailand were employing genre-based approaches in developing their syllabuses, materials and curriculum (Derewianka, 2003).

Currently, many studies on SFL-based genre approach have shown improvement in students' genre writing ability. Some studies reported this approach resulted in the promotion of learners' generic structural awareness. For example, Chen and $\mathrm{Su}$ (2012) and Feez (2002) reported that this approach was effective in learners' summarization ability, especially their organization of narration text structure. Carstens (2009) investigated the effectiveness of using genre-based approach with SFL grammar as the theoretical framework for teaching academic writing to second-year undergraduate students of Humanities at the University of Pretoria and found a general improvement of writing ability. Although it was challenging for many tertiarylevel learners to acquire specific knowledge and skills to write particular academic genre texts, genre-based writing had the capability to enhance their writing abilities. Some other studies on SFL genre-based teaching and learning found that learners improved their understanding of the logico-semantic relationship. For example, in Srinon's (2011) study, learners' use of resources to construct a logico-semantic relationship increased, that is, the frequency of using single-clause sentences reduced, and sentences including hypotaxis and parataxis increased. In addition, some studies indicated genre awareness improvement with the SFL-based instruction. Yasuda (2011) experimented the SFL genre approach on 70 Japanese undergraduates and confirmed that this approach enabled the students to improve their genre awareness and command of lexicogrammatical features. In recent three years, more studies were conducted to provide evidences for genre-based pedagogy. Nagao (2019) took the genre of discussion as an example to investigate the changes in English as a Foreign Language (EFL) learners' psychological attributes in relation to awareness of the lexicogrammatical features and generic structures. The study indicated specific improvements in genre-based writing, particularly among low proficiency English learners. Yi He (2021) took netvertisement writings as an example to explore the persuasive strategies in a Chinese college from the perspective of SFL approach and got positive results.

In specific classroom teaching, genre-based pedagogy takes different forms. Among them, curriculum cycle is one of the best-known approaches to writing, which scaffolds the process of developing different genres. In order to facilitate and conceptualize literacy learning in schools, many researchers (Cheng, 2005; Hyland, 2003) emphasized the importance of curriculum cycle, which included deconstruction, joint construction and independent construction as initiated by Rothery (1994). Educational linguists and researchers later adapted this cycle into several other versions for different purposes. For example, Derewianka (1990), Foley (2012) and Butt, Fahey, Feez, Spinks and Yallop (2001) adapted it into a four-stage model by adding the stage of context exploration. Some other researchers adapted the four-stage model into a five-stage model: Sharpe and Thompson (1998) stress more on developing the context and Derewianka and Jones (2016) divide context exploration into two specific stages. 
Many studies reported the benefits of applying curriculum cycle to explore the degree to which genre-based teaching allows learners to gain genre awareness and improves writing quality when they write argumentative essays (Tsou \& Lin, 2013). Syarifah and Gunawan (2015) observed improvement in six EFL learners' writing performance of a discussion genre text. In particular, the social function, schematic structure, and language features improved because of the cycle model. Jamrassri (2018) experimented with 32 English Education students at Phranakhon Rajabhat University by using the curriculum cycle model to develop the students' "exposition" genre. The study of Nagao (2018) indicated that applying the curriculum cycle and a genre-based approach to writing instruction had the potential to enhance EFL students' awareness of generic structure. Yu Huang and Lawrence Zhang (2020) did an intervention study of process-genre approach in two English classes at a university in China and found significant increases in the intervention group's writing performance and little improvement in the comparison group. Mirallas (2021) experimented the genre approach in the form of Reading to Learn Pedagogy to the teaching of Science Research Article writing to researchers in an EFL context and found it was effective. But there are also some studies which do not provide evidence for the teaching effects and genre awareness improvement. For example, Viriya and Wasanasomsithi (2017) applied the curriculum cycle to writing lessons for a 12-week period. The target for these learners was to produce a genre text that was informative and persuasive. However, there was little improvement in the perspectives of learners' awareness of the readerwriter relationship and what they should write. Viriya and Wasanasomsithi (2017) concluded that because these learners' discourse community was within the classroom, and they knew that their audience, i.e., the readers of the text, would simply be their teachers. Therefore, awareness of the reader-writer relationship did not improve significantly in the post-task.

To sum up, the previous studies experimented on different genres and reported the teaching effects of genre pedagogy in improving students' genre writing ability from different perspectives. It can be concluded that the teaching effects of genre pedagogy has been discussed well in both theoretical and empirical fields. But total agreement has not been reached. Besides, few studies investigated students' attitudes and perceptions towards the pedagogy while this investigation is actually essential to explore the teaching effects from the whole perspective. This is also the research gap of this study. The present study will firstly present the instruction model and its implementation process. After that, a questionnaire and an interview on students' perceptions and attitudes towards the designed teaching model of curriculum cycle will be reported and analyzed in detail.

\section{Methods \\ Participants}

The present study takes the English majors in an ordinary Chinese university Chongqing Technology and Business University (CTBU) as the research subjects. Convenience sampling method was used to choose the samples. Thirty-four second-year university students from a natural class taught by the researcher in the English department of CTBU were chosen as samples to take part in the study. They were assigned into six groups (with five or six students in each group) to engage in the various learning activities. The experimental teaching lasted for one semester, starting from September 2020 and ending in December 2020. 


\section{Research Instruments}

The research design of the study is a mixed one by including both the quantitative and qualitative methods. The quantitative research instrument is the questionnaire and the qualitative instrument is the interview. The questionnaire is a four-point Likert scale to measure the participants' opinions towards each item for the sake of avoiding students' tendency of choosing the neutral choice of " 3 ". To be specific, 1 means strongly disagree, 2 means disagree, 3 means agree, 4 means strongly agree. In order to help the students to get a clear understanding of the questionnaire items, both the Chinese and English version of the questionnaire was provided to students to collect the data. The details of the questionnaire are shown in Appendix A: The Perceptions and Attitudes Questionnaire.

Then in order to provide extra and in-depth evidence for the questionnaire results, a semiconducted interview was implemented to explore students' other comments for the teaching program. The interviewees were randomly sampled from the participants to provide extra data and further evidence for the questionnaire findings. To get the reliability of the data, the interview was conducted in English.

\section{Research Procedure}

This study is an experimental study on genre-based pedagogy. Based on the previous studies, the present study adapted the cycle of Foley (2012) and Derewianka (2016), and designed a four-stage curriculum cycle consisting of context exploration, text deconstruction/modelling, guided practice and teacher-led construction, and independent group construction to do the experiment. In these stages, a variety of language activities of listening, speaking, reading and writing are involved to develop students' knowledge in the field of persuasion as well as to enhance their comprehensive language skills and literacy skills. The details and language learning activities for each of those stages is explained in detail in the following section.

\section{Stage One: Context Exploration}

It contains two parts: building knowledge of the field and supported reading. In this stage, the teacher firstly introduces the topic and target genre. Then, the teacher prepares some language learning activities such as discussions, brainstorming, think-pair-share activities, handson activities such as problem-solving, research activities such as jigsaw tasks, guest speakers etc. to help students become familiar with the topic. Then for the supported reading, it is closely related to the field-building stage as it offers opportunities to expand students' knowledge of the curriculum cycle topic by engaging students in the reading activities related to the target genre. Activities suitable for it vary from teacher-led reading, to shared reading, and then to guided, collaborative and independent reading following the general shift from teacher explicitly modelling aspects of the reading process to students' independence.

\section{Stage Two: Text Deconstruction}

It is also called the explicit instruction. In this stage, the focus shifts from field to genre. The teacher introduces the model text types they are learning to use through the reading activities in metalanguage, including the social purpose and textual features of persuasion. To be specific, there are the generic text structure, the characteristic language features, especially lexico- 
grammatical features, and the reasons for the choice of particular language forms from the perspective of three metafunctions of SFL. These textual features are picked up from the likely use of persuasion in daily life and in school settings, from both the spoken and written corpus of persuasion, and are established as a template for the participants to refer to while writing. To be particular, the generic structure adapted from Foley (2012) and the language features are based on experiential function, interpersonal function and textual function. Through this stage's explicit instruction, the teacher explicitly and systematically shows students how the meanings in the text are shaped by the context in which they are used, how the meanings in the text are unified by textual structure, and how the meanings in the text are encoded in lexicogrammar.

\section{Stage Three: Guided Practice and Teacher-led Construction}

It is a critical stage for students to practice what they have learned in the second stage. In fact, it consists of two steps: guided practice and joint construction. The first one is the guided practice. In this process, the teacher provides similar reading passages in the handouts and guides the students to discuss and analyze the patterns and language features according to persuasion textual feature template they have used in the explicit instruction phase. The other step is the teacher-led construction. After students become familiar with and are quite clear about the persuasion textual features, the teacher and students jointly work together towards the targeted writing task with the teacher being the guide.

\section{Stage 4: Independent Group Construction}

In this stage, students take over responsibility for the creation of the text. They are assigned in groups in mixed language levels and work together to construct a text on a topic closely related to the field and genre but different from the joint construction writing task in Stage Three. In the process, they can discuss and negotiate to provide feedback to each other such as responding to the meanings of the text, or editing according to the textual feature template of persuasion. In their group construction, the teacher can provide explicit feedback to students on the preparation of their drafts and final texts.

The experimental teaching was carried out for one semester, consisting of 32 hours in 16 weeks. Three iterations of the above-mentioned curriculum cycle were repeated with different topics. At the end of teaching experiment, a questionnaire survey and an interview were conducted to explore students' attitudes and perceptions towards the designed teaching pedagogy.

\section{Data Collection and Analysis}

The data were collected from the questionnaire survey and interview conducted at the end of the experimental period. All the 34 participants in the study were required to finish the questionnaire. Their confidentiality was maintained and the participants were asked to cooperate willingly so that the researcher could obtain accurate and reliable data. Thirty-four questionnaires were gathered and collected in total. Then the percentages and numbers for each response of each questionnaire item were calculated and analyzed by computer programs. Then the interview data collected from random sampled participants were analyzed by content analysis to provide extra information.

\section{Findings}


The findings of the study included both the questionnaire and interview findings covering six aspects: (1) Students' mastery of the textual feature of persuasion, including their selfevaluation on whether students can identify the generic structure and language features and on whether students can write persuasions according to the teacher's instruction for questionnaire Items one to five. (2) Whether they have the awareness of genres by evaluating an effective persuasion for questionnaire item six. (3) Their confidence on writing an effective persuasion for questionnaire item seven. (4) Their attitudes towards group construction process for questionnaire items eight and nine. (5) Students' interests and enjoyment for the application of the teaching model for questionnaire item ten. (6) Other comments for the teaching program from the interview.

\section{Mastery of Textual Features}

For the mastery of textual features, there are five items in the questionnaire, which can be subdivided into the following two aspects: Item one and two for their ability to identify and analyze the textual features, and Item three to five for their ability to write with the textual features.

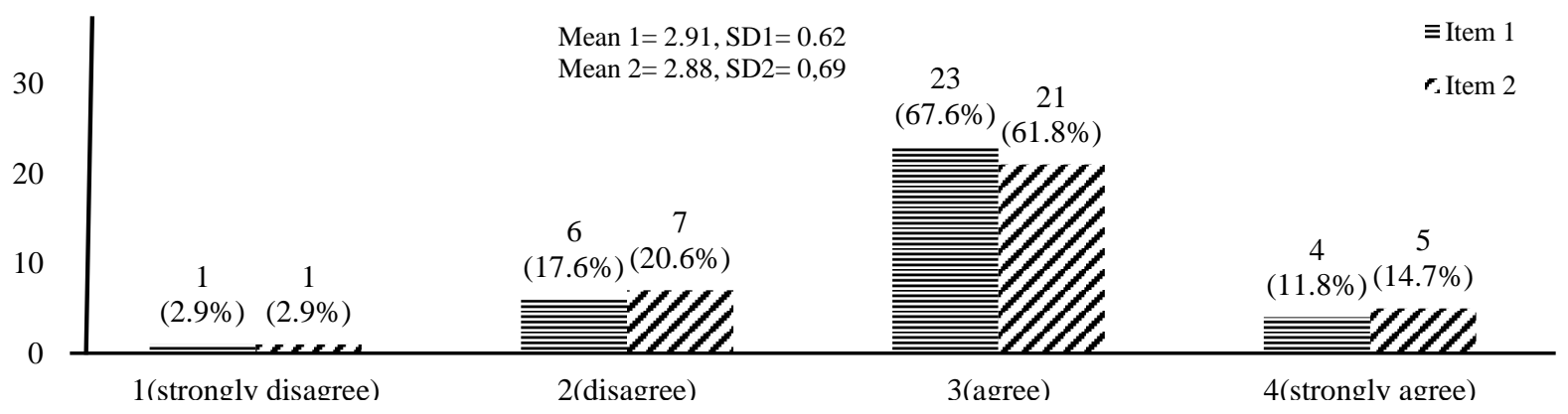

Figure 1. Self-evaluation on the ability to identify textual features

Figure one is for the first aspect "students' self-evaluation on the ability of identifying the textual features of persuasion" and most of them had a positive comment. The first item "I can easily find the generic structures while reading the persuasive essays" is about their ability to identify the generic structure. Most students thought they could easily identify the generic structure of persuasion. Twenty-three students $(67.6 \%)$ choose to agree with the statement and four of them $(11.8 \%)$ choose to strongly agree. Only one student strongly disagreed and six students disagreed, with the two accounting for $20.5 \%$. That is to say, about $80 \%$ of them thought they could easily point out the generic structure of persuasion now. The second item "I can point out the important language features such as general participants, types of verbs, evaluative words, auxiliary verbs, connective words etc. while reading the persuasion text types" is to test their self-evaluation on the ability to identify the language features of persuasion. Twenty-one students (61.8\%) agreed with and five students (14.7\%) strongly agreed with the item. Only eight students $(23.5 \%)$ disagreed or strongly disagreed with this item. Most of them (more than 75\%) thought they could easily analyze the language features while reading persuasions. 

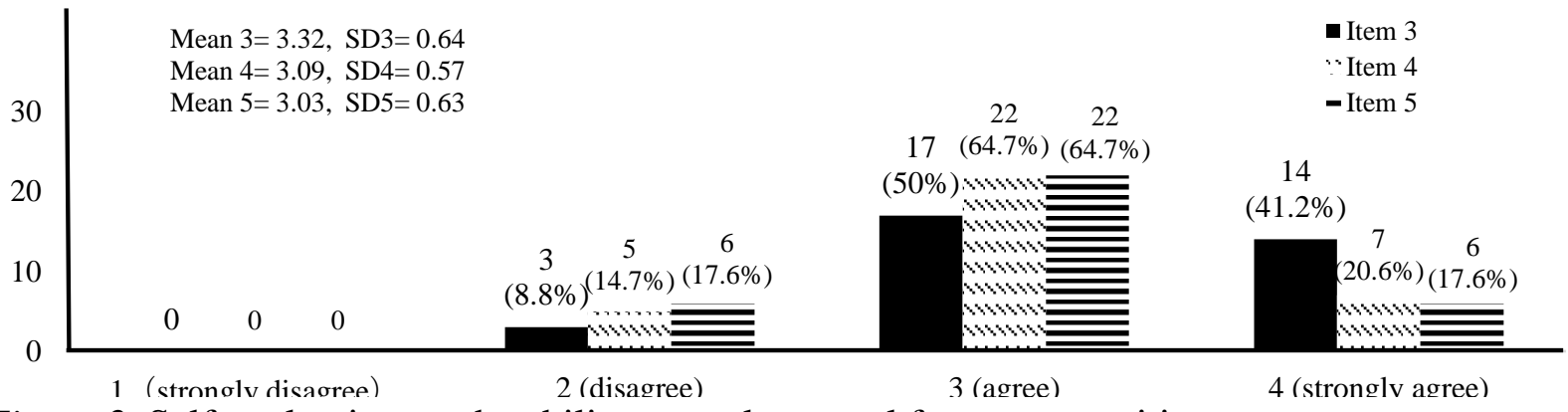

Figure 2. Self-evaluation on the ability to apply textual features to writing

For the second aspect, self-evaluation on whether students can write effective persuasions by following the textual features presented in the teaching instruction. Items three and five investigated this aspect of students' ability: Item three is about the ability to plan the framework of persuasion; Item four is about the ability to use the textual features in persuasive writings; Item five is about the ability to revise the writing according to the textual features. Figure two shows that most of the responses for the three questions showed strong agreement. The means for each of the three items were quite high, and the students had strong agreements with these items. Specifically, for item three, "Before writing a persuasive essay, I can write the outlines/planning framework of the writing task", only three students $(8.8 \%)$ disagreed with this statement, 17 students (50\%) agreed and 14 students (41.2\%) strongly agreed with it. That is, more than $90 \%$ of the students thought they could write an effective planning framework, with the major points contained in persuasion. Then for item four "I can write a persuasive essay following the convention we talked about in classroom instruction", only five students (14.7\%) showed disagreement, no students showed strong disagreement, twenty-two students $(64.70 \%)$ agreed that they could write the planning framework and seven students $(20.60 \%)$ even showed strong agreement. Finally, for item five "I can revise the content, structure and language of my writing according to the checklist table for persuasive writing provided by my teacher", more than $80 \%$ of the students (28 students) (82.3\%) showed agreement and only six students (17.6\%) thought they could not do that, no students expressed strong disagreements.

\section{The Genre-Awareness of Persuasion}

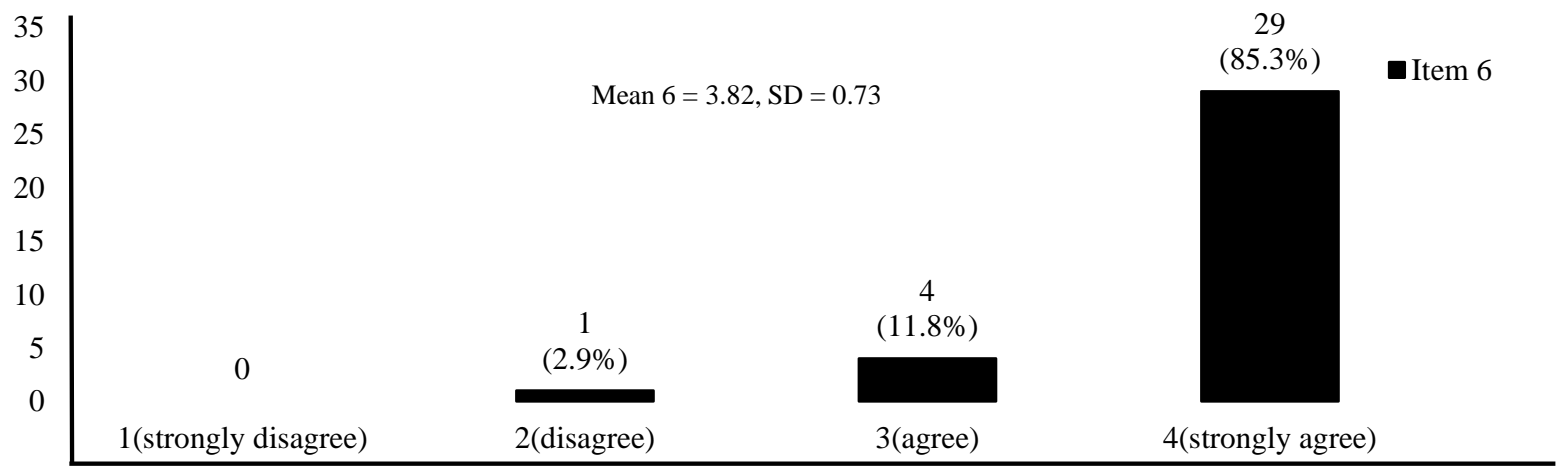

Figure 3. Self-evaluation on students' genre-awareness 
The second part of the questionnaire was actually to investigate students' genre-awareness. Item six "This semester's instructional model let me know what is an effective persuasive writing" was designed to survey this aspect. Figure three indicated that the mean of the item was very high, only one student showed disagreement, four students (11.8\%) and 29 students (85.3\%) showed agreement and strong agreement respectively.

\section{Confidence in writing an effective persuasion}

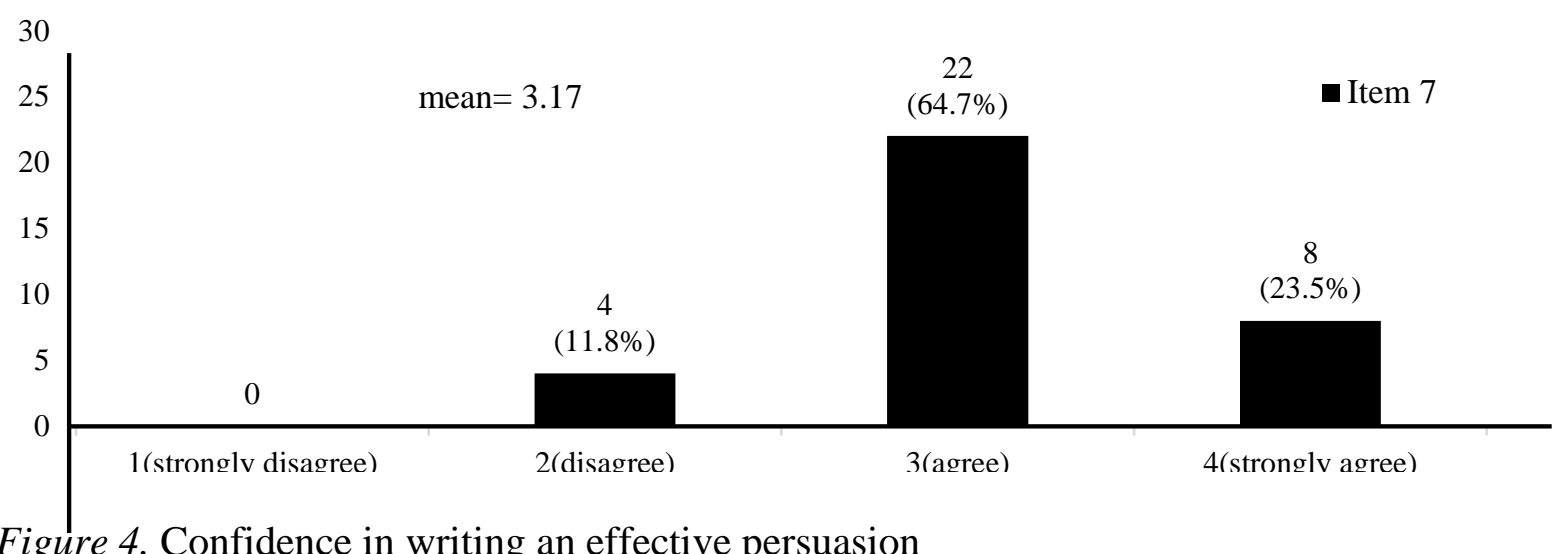

Figure 4. Confidence in writing an effective persuasion

Item seven "After this semester's instruction, I have the confidence to write an effective persuasive writing." investigated students' confidence of writing an effective persuasion after the instruction. Figure four reveals that after the instruction, nearly 90\% (30 students) of them were confident to write an effective persuasion. The mean for this item was also quite high. Only four students $(11.80 \%)$ showed disagreement, the other 30 students showed agreement or strong agreement.

\section{Attitudes Towards Group Writing}

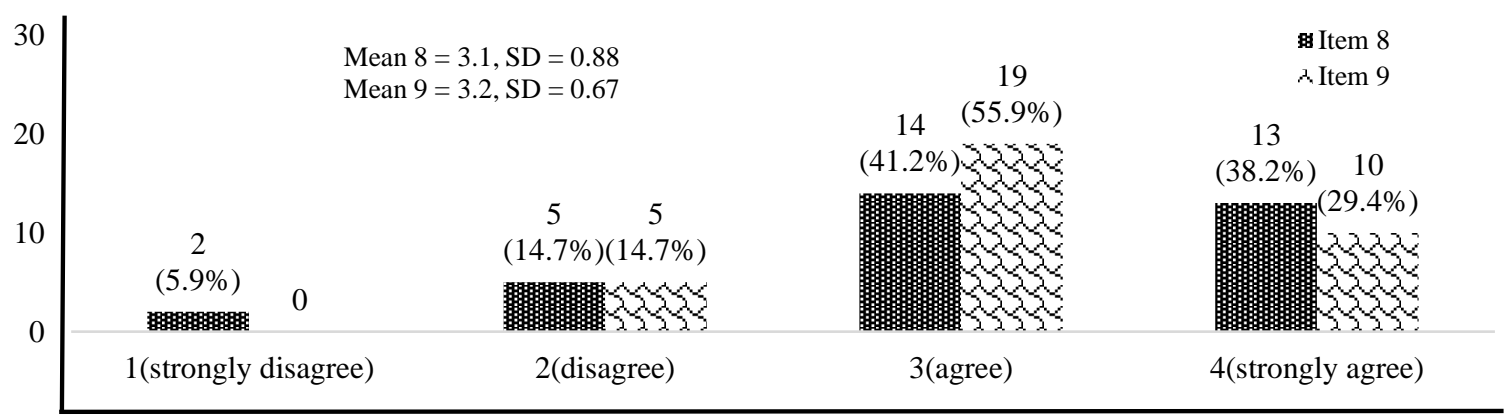

Figure 5. Attitudes towards group writing

Items eight and nine in the questionnaire were to investigate students' attitudes towards the most important stage of the curriculum cycle "group writing". As indicated in figure five, the means of these two items are 3.1 and 3.2 respectively (both above three), which means that from the total perspective, students showed positive attitudes towards group writing. For item eight "I like the group construction stage", twenty-seven students (79.4\%) expressed their enjoyment of group 
writing, but some students did not like it, seven students showed either strong disagreement or disagreement, a percentage of $20.6 \%$. For item nine "The group writing process has improved my writing ability", the percentage of agreement was higher than item eight. Among them, twenty-nine students $(85.3 \%)$ thought they could improve their writing ability in group writing process. Only five students showed disagreements. Generally, the above figure five suggested that although a few students showed their negative attitudes towards group writing, but still most students thought group writing could promote their writing ability and they liked the process of group cooperation in writing.

\section{Interests in Application of Curriculum Cycle}

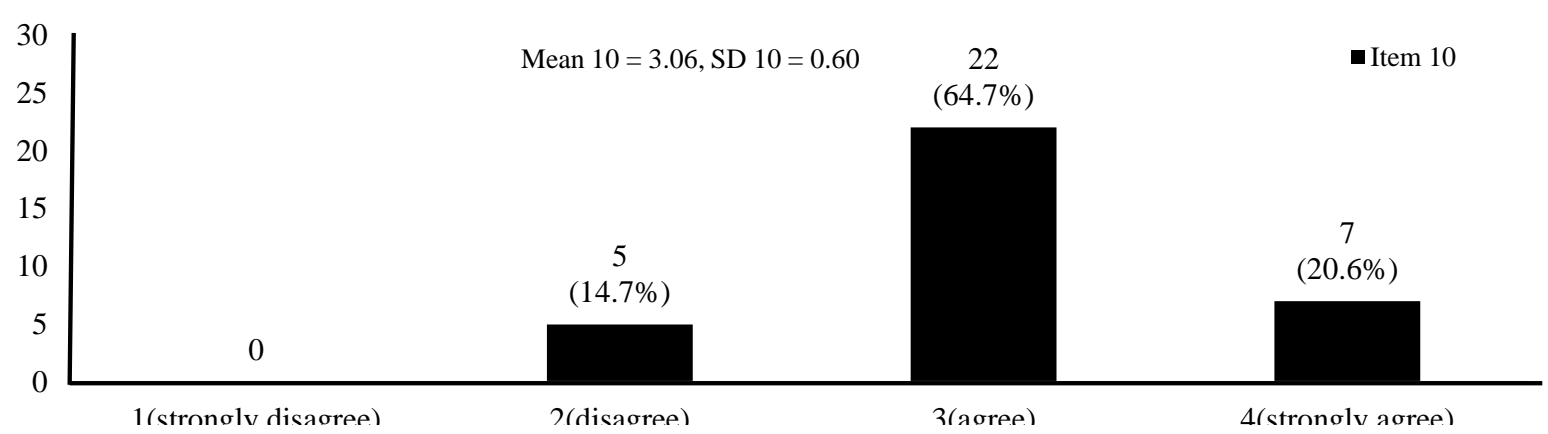

Figure 6. Interests in application of curriculum cycle to other genres

In order to have a further understanding of the students' interests and enjoyments in the curriculum cycle applied in this teaching instruction, item ten "I enjoy learning different types of writings following the teaching pattern we adopt this semester" was to investigate it from another perspective. Figure six reveals that more than $80 \%$ of the participants (29 students) liked the teaching approach. Only five students $(14.7 \%)$ showed their dislike for the teaching pattern, none showed strong dislike.

\section{Other Comments Related to the Teaching Program}

In order to explore students' attitudes and perceptions towards the model, an interview on the designed question "Other comments you may have or want to add about the teaching program" was implemented after the questionnaire to investigate other comments of the participants and provide in-depth data. Nine students were interviewed to give comments about the teaching program. These comments focused on the implementation of curriculum cycle and group writing process.

First are some general comments and suggestions they gave for the implementation of curriculum cycle. Some students gave further specific comments, for example, Rino (a male participant) mentioned what he can learn from the teaching model "The teaching method was practical and interesting. I could learn a lot from the revision process and the teacher's feedback...". Then other participants gave comments from other aspects and teaching suggestions, mentioning "needing more model exercises and more detailed analysis of each paragraph of the essay", "being practical, but still being difficult to control the use of some language features in writing", "hoping to practice collecting ideas related to a topic for not having many useful ideas to illustrate an argument for an effective persuasion" and "give us more reference materials to accumulate." 
In addition, there are also some other comments about the group writing process, some were positive, such as Ava (a female participant) mentioning "In the group writing, we can learn many writing techniques and it is a good way to learn." But some participants hold negative attitudes towards group writing as they mentioned "to reduce the frequency of group writing and increase individual writing", "the unreasonable arrangements of the group members", "the unwillingness to cooperate with some students in the groups" and "reducing and disliking group writing".

\section{Discussions}

\section{Students Have High Self-Evaluation on Mastery of Textual Features After Instruction.}

The results of the above figure one and two indicated that most students (more than 3/4) could identify and analyze the textual features of persuasion including the generic structure and language features. Besides, most students (about 80\%) thought they had the ability to write an effective persuasion according to the teaching program. They agreed with the point that the teaching program was quite useful and helpful for their writing of persuasion. They thought they had mastered the important textual features of persuasion. The typical feature of curriculum cycle is explicit instruction and this "visible pedagogy" can make what is to be learned and assessed clear to students. This finding is corresponding with most the current genre-based studies (Yasuda, 2011; Nagao, 2018; Jamrassri, 2018) as supporters of genre-based pedagogy suggest that students learn best when explicit instruction of genre knowledge is given to students, as explicit understanding of the types of texts can allow students to read and write better. Through this explicit instruction, the language and structural features in different types of texts are also presented to students explicitly, which allows them to improve their own writing as they have been "empowered" (Lee \& Wong, 2013).

\section{Students Have High Self-Evaluation on Genre Awareness Development.}

The above figure three indicated that nearly all students, except one, strongly agreed with the item about their genre awareness self-evaluation and thought they could evaluate persuasions and had formed the awareness. After the instruction, they learned to evaluate persuasion in the perspective of genre features, which means that they know what kind of persuasion was effective, what features the genre of persuasion should have. This is corresponding with the research results of Nagao $(2018,2019)$, students improved their awareness of generic structure and lexicogrammatical features. Students in this study improved their genre awareness from both perspectives of generic structure and language features. Through repeated practice of commenting and analyzing other writings, students can master the basic features of a particular genre and this genre awareness can then contribute to developing students' writing ability.

\section{Students Have Strong Confidence to Write Standardized Persuasions.}

Confidence is another important factor in developing one's ability. It gives people greater self-worth, thus making them feel more valuable. Besides, it can encourage one to recognize and appreciate one's talents and skills. In writing, if one is confident about their writing ability, they will write fast and more logically, therefore, the writing quality will be much higher than those written by students with low-level self-confidence. After the instruction, about $90 \%$ of the participants have strong confidence to write effective persuasion and this confidence helps them develop their genre writing ability. 


\section{Students Think Highly of Group Collaborative Writing.}

Attitudes are the individual's positive or negative evaluation of performing the particular behavior of interest (Ajzen, 1988). In the language teaching and learning fields, attitude is an important factor to reflect the efficiency of the teaching instruction. If students hold positive attitudes towards the teaching model, they will follow it and learn from it greatly. On the contrary, the teaching effects will be less effective. The results of figure four revealed that most students held positive attitudes towards group writing and thought it could improve their writing ability. With positive attitudes, students will work positively and collaborate with each other well in writing practice. Nystrand $(1989$, p70) pointed out that writing actually involved more than the generation, organization, and translation of ideas into text. Instead, each act in the writing process was an episode of interaction. Writing in nature is a process of interaction, but the patterns in collaborative writing students were engaged in were generally reported to have four patterns just as Storch (2002a) indicated: collaborative, dominant/dominant, dominant/passive, and expert/novice. Among them, the most efficient one was the collaborative pattern and should be encouraged to make everyone have the equal opportunity to share and learn in group work. But the deterministic factor of efficient pattern of interaction relies on the distribution of group members which involves many factors except language levels. This implicates that researchers need to put more factors into consideration in research design process.

In addition, through collaborative writing, the writing efficiency can be promoted because students are impelled to make decisions about the language that they need to express ideas, and thus have to formulate the structure quickly in the process of producing a text together (Suzuki, 2008). They can make use of every group member's strengths, for example some being good at grammar, some being good at collecting ideas, some being good at revising, some being good at word choice etc.. Besides, not only higher-level students provide scaffolding for lower-level students, but also every group member's strength can be the scaffolding for those who lack or are poor at the points. But one point should be noted, appropriate collaborative interaction pattern should be encouraged to and thus, through collaborative group writing, students can learn writing well. In addition,

\section{Students Show Interests in Applying the Cycle Teaching Model to Learning Other Genres.}

The significance of the designed teaching model in this experimental study is not only to the writing practice for the genre of persuasion, but also help students to learn the writing of other genres. Students' interests to apply this teaching model to other genre writing is a reflection of the efficacy of the teaching model. The above research findings reveal that generally, most of the participants gave positive comments on the cycle model and thought it was feasible to apply it to learning other genres. This indicates that the present designed curriculum cycle is an effective genre writing teaching and learning model, and that the model can be applied to learning other text types. In EFL writing fields, many researchers have successfully applied this pedagogical modal to learning other types of text, such as summary writing of Yasuda (2015), argumentative essays of Tsou and Lin (2013) and Huangyu and Lawrence Zhang (2020), academic writing of Emilia (2011), and netvertisement writings of Yi He (2021). But it should be noted that there was a minority of the students who did not like learning with genre writing model for what seem to be personal reasons such as: not liking the group they were working with or preferring to enrage in writing in a more individual manner as indicated below. 


\section{Students Have More to Say About the Teaching Program}

The comments given in the interview indicate that many of them gave positive comments for the cycle in general, but their comments also showed that they still had some problems in some stages of the cycle. For example, in context exploration stage, especially for some topics they were not familiar with, they did not have enough background knowledge, relevant vocabulary and ideas to illustrate the arguments. In the future teaching, teaching activities in this stage can be added more, especially more background materials can be provided for students to accumulate. Another problem occurred in the context deconstruction stage. Although in each curriculum cycle, some model texts were analyzed, some students still had problems in analyzing the specific features of persuasion, and they needed more practices to reinforce the standards of an effective persuasion. Besides, the interview data reveal that more factors such as the intimate relationship among group members, personality and personal interests should be considered for group collaborative writing, especially in the assignments of group members. The iterations of curriculum cycle can be adjusted according to their progress in writing and particular situations.

\section{Conclusion}

The present study adopted a mixed research method by applying the quantitative instrument of questionnaire and the qualitative instrument of interview to investigate students' perceptions and attitudes towards the designed SFL-based genre pedagogy. The results of the questionnaire survey indicate that nearly $80 \%$ of the participants hold positive attitudes towards items indicated in the questionnaire. Most of them think highly of the genre-based teaching pedagogy: they mastered the generic structure and language features for the genre and could write an effective persuasion according to the procedure given in the teaching pedagogy, in terms of both group and individual writing. Some students still had problems, more often in terms of their personalities rather than mastery of the language features, textual organization, and building enough confidence to write effectively. However, such scaffolding in groups together with the teacher over the semester indicated that this genre-based pedagogy has the potential to improve writing. And the interview data generally confirmed with the questionnaire data, but it indicated more, especially in the implementation of particular stages of curriculum cycle, the interactive pattern of group work and the assignments of group members.

\section{Acknowledgements}

The author extends her appreciation to the deputyship for Chongqing Technology and Business University, and Chongqing Federation of Social Sciences in China for funding this research work through the two projects numbers (1951035 and 2019PY25 respectively).

\section{About the Author \\ Feng Chen is an English Teacher at Zhejiang Ocean University, China. She is interested in second language teaching and learning, and is currently doing Ph.D. ELT in the English Department, School of Human Sciences, Assumption University, Thailand. Email: 406956449@qq.com. https://orcid.org/0000-0002-6701-6299.}

\section{References}

Bernstein, B. (1975). Class and pedagogies: Visible and invisible. Educational Studies. 1 (1), 2341. 
Butt, D., Fahey, R., Feez, S., Spinks, S., \&Yallop, C. (2001). Using Functional Grammar: An Explorer's Guide. National Centre for English Language and Research.

Carstens, A. (2009). The effectiveness of genre-based approaches in teaching academic writing: Subject-specific versus cross-disciplinarity emphases, (Unpublished Doctoral dissertation). University of Pretoria, Africa.

Chen, Y. S., \& Su, S. W. (2012). A genre-based approach to teaching EFL summary writing. ELT Journal, 66(2), 184-192. https://doi.org/10.1093/elt/ccr061.

Cheng, A. (2005). Genre and learning: Exploring learners and learning in the ESP genre-based framework of learning academic writing, (Unpublished Doctoral Dissertation). The Pennsylvania State University, America .

Derewianka, B. (1990). Exploring How Texts Work. Primary English Teaching Association.

Derewianka, B. (2003). Trends and issues in genre-based approaches. RELC Journal, 34(2), 133154. Doi: $10.1177 / 003368820303400202$.

Derewianka, B., \& Jones, P. (2016). Teaching language in context ( $2^{\text {nd }}$ ed.). Oxford University Press.

Emilia, E. (2011). Teaching Academic Writing: A Critical Genre-Based Approach in an EFL Context. Saarbrucken Germany: LAP Lambert Academic Publishing.

Feez, S. (2002). Heritage and innovation in second language education. In A. M. Johns, (Ed.), Genre in the Classroom: Multiple Perspectives, (pp. 43-69). Lawrence Erlbaum Associates Publishers.

Foley, J. (2011). Grammar, Meaning and Discourse. Assumption University Press.

Foley, J. (2012). Unscrambling the Omelette: Second Language Acquisition: Social \& Psychological Dimension. Assumption University Press.

Halliday, M. A. K. (1978). Language as Social Semiotic: The Social Interpretation of Language and Meaning. Hodder Arnold.

Halliday, M. A. K., \& Matthiessen, C. M. I. (2014). An Introduction to Functional Grammar $\left(4^{\text {th }}\right.$ ed.). Routledge.

Hyland, K. (2003). Genre-based pedagogies: A social response to process. Journal of Second Language Writing, 12, 17-29.

Jamrassri, P. (2018). The effectiveness of using curriculum cycle model on EFL writing ability of students at Phranakhon Rajabhat University, (Unpublished Doctoral Dissertation). Assumption University, Thailand.

Lee, I. \& Wong, K. (2013). Bringing innovation to EFL writing: The case of a primary school in Hong Kong. Asia-Pacific Education Researcher, 23, 159-163. https://doi.org/10.1007/s40299-013-0149-y.

Mirallas, C. A. (2021). Students' perceptions of a scientific writing course: SFL Genre Pedagogy in an EFL context. Signo, Santa Cruz do Sul, 46(86), 86-102. Disponívelem: https://online.unisc.br/seer/index.php/signo/article/view/15900.

Nagao, A. (2018). A genre-based approach to writing instruction in EFL classroom contexts. English Language Teaching, 11 (5), 130-147.

Nagao, A. (2019). The SFL genre-based approach to writing in EFL contexts. Asian-Pacific Journal of Second and Foreign Language Education, 4(6), 1-18. https://doi.org/10.1186/s40862-019-0069-3.

Nystrand, M. (1989). A social-interactive model of writing. Written Communication, 6 (1), 6685. 
Price, L., \& Price, J. (2002). Why genres matter. Hot text: Web Writing that Works (pp. 272279). Berkeley, CA: New Riders.

Raimes, A. (1983). Techniques in Teaching Writing. Oxford University Press.

Rose, D., \& Acevedo, C. (2006). Designing literacy in servicing: Learning to read: Reading to learn. In Proceedings of the Australian Systemic Functional Linguistics Conference, University of New England.

Rose, D., \& Martin, J. R. (2012). Learning to write, reading to learn: Genre, knowledge and pedagogy in the Sydney school. Equinox.

Rothery, J. (1989). Learning about language. In R. Hasan \& J. R. Martin (eds.), Language Development: Learning Language, Learning Culture (pp. 199-256). Meaning And Choice in Language: Studies for Michael Halliday. Volume XXVII. Ablex Publishing Company.

Rothery, J. (1994). Exploring Literacy in School English (Write It Right Resources for Literacy and Learning). Sydney: Metropolitan East Disadvantaged Schools Program.

Sharpe, T., \& Thompson, J. (1998). Accessing Learning. Sydney: NSW Catholic Education Office.

Silva, T. (1990). Second language composition instruction: Developments, issues, and directions in ESL. In B. Kroll (Ed.), Second Language Writing: Research Insights for the Classroom (pp. 1-23). Cambridge University Press.

Srinon, U. (2011). A longitudinal study of developments in the academic writing of Thai University students in the context of a genre-based pedagogy, (Unpublished Doctoral Dissertation). University of Adelaide, Australia.

Storch, N. (2002a). Patterns of interaction in ESL pair work. Language Learning, 52, 119-158.

Syarifah, E. F., \& Gunawan, W. (2015). Scaffolding in the teaching of writing discussion texts based on SFL genre-based approach. English Review: Journal of English Education, 4(1), 39-53. https://doi.org/10.25134/erjee.v4i1.306.

Tsou, W., \& Lin, V. (2013). The effects of genre-based writing instruction on college English academic literacy. Bulletin of Educational Research, 59(2), 115-151. https://doi.org/10.3966/102887082013065902004.

Viriya, C. \& Wasanasomsithi, P. (2017). The effect of the genre awareness approach on development of writing ability. International Forum of Teaching and Studies, 13(1), 1122.

Williams, J. (2007). Teaching Writing in Second and Foreign Language Classrooms. Beijing: World Publishing Corporation.

Yasuda, S. (2011). Genre-based tasks in foreign language writing: Developing writers' genre awareness, linguistic knowledge, and writing competence. Journal of Second Language Writing, 20(2), 111-133. https://doi.org/10.1016/j.jslw. 2011.03.001.

Yasuda, S. (2015). Exploring changes in FL writers' meaning-making choices in summary writing: A systemic functional approach. Journal of Second Language Writing, 27, 105121. https://doi.org/10.1016/j.jslw.2014.09.008.

$\mathrm{Yi} \mathrm{He,} \mathrm{(2021).} \mathrm{Developing} \mathrm{persuasive} \mathrm{strategies} \mathrm{in} \mathrm{netvertisement} \mathrm{writings} \mathrm{in} \mathrm{a} \mathrm{Chinese} \mathrm{college:}$ A Systemic Functional Linguistics approach, (Unpublished Doctoral Dissertation). Assumption University, Thailand.

Yu, H \& Lawrence, Z. (2020). Does a process-genre approach help improve students' argumentative writing in English as a foreign language? findings from an intervention study. Reading \& Writing Quarterly. 36 (4), 339-364. 


\section{Appendix A: The Perceptions and Attitudes Questionnaire}

Directions: Dear Sir/ Miss, this questionnaire is designed to investigate your perception of the teaching instruction on persuasive writing. Please tick your choice under the corresponding number, 1 means strongly disagree, 2 means disagree, 3 means agree, 4 means strongly agree. The questionnaire is just for academic study use, the responses will not affect your scores in the course and all of your responses will be keep in secret, please make the choices according to your real learning situations.

同学你好: 本问卷旨在调查大家对本学期论说文教学模式的看法和理解。请在相应的选项 后打勾, 1 代表非常不赞同, 2 代表不赞同, 3 代表赞同, 4代表非常赞同。本问卷仅用于学 术研究, 你的答案不会影响你课程的分数, 你所有的答案也将被保密, 请根据自己的真实 情况作答，谢谢支持与配合！

\begin{tabular}{|c|c|c|c|}
\hline No & Items & 1 & \begin{tabular}{l|l}
2 & 3
\end{tabular} \\
\hline 1 & $\begin{array}{l}\text { I can easily find the generic structures while reading the persuasive essays. 在阅 } \\
\text { 读论说文时我能很快地找出论说文的通行结构。 }\end{array}$ & & \\
\hline 2 & $\begin{array}{l}\text { I can point out the important language features such as general participants, types } \\
\text { of verbs, evaluative words, auxiliary verbs, connective words etc. while reading } \\
\text { the persuasion text types. 在阅读论说文时我能找出论说文重要的语言特征, } \\
\text { 如表泛指的主语, 动词的种类, 评价性或者情感表达词, 情态助动词, 要 } \\
\text { 用的连接词等。 }\end{array}$ & & \\
\hline 3 & $\begin{array}{l}\text { Before writing a persuasive essay, I can write the outlines/planning framework of } \\
\text { the writing task. 在写论说文前, 我可以写出该写作任务的计划框架。 }\end{array}$ & & \\
\hline 4 & $\begin{array}{l}\text { I can write a persuasive essay following the convention we talked about in } \\
\text { classroom instruction.我可以根据这学期在课堂上讲的论说文结构和语言要 } \\
\text { 求写出一篇论说文。 }\end{array}$ & & \\
\hline 5 & $\begin{array}{l}\text { I can revise the content, structure, and language of my writing according to the } \\
\text { checklist table for persuasive writing provided by my teacher. 我可以根据老师 } \\
\text { 提供的论说文修改对照表修改文章的内容, 结构和语言特征等。 }\end{array}$ & & \\
\hline 6 & $\begin{array}{l}\text { This semester's instructional model let me know what is a good persuasive } \\
\text { writing. 这学期的教学让我懂得了什么的文章是一篇好的论说文。 }\end{array}$ & & \\
\hline 7 & $\begin{array}{l}\text { After this semester's instruction, I have the confidence to write an effective } \\
\text { persuasive writing. 这学期的教学让我有了信心写出一篇好的论说文。 }\end{array}$ & & \\
\hline 8 & I like the group construction stage.我喜欢小组合作写作的过程。 & & \\
\hline 9 & $\begin{array}{l}\text { The group writing process has improved my writing ability.小组合作写作可以 } \\
\text { 提高我的写作水平。 }\end{array}$ & & \\
\hline 10 & $\begin{array}{l}\text { I enjoy learning different types of writings following the teaching pattern we } \\
\text { adopt this semester.我喜欢按照这种教学模式学习写作其他文体的写作。 }\end{array}$ & & \\
\hline
\end{tabular}

